\title{
THE RELEVANCE OF SOCIO-LEGAL STUDIES IN LEGAL SCIENCE
}

\author{
Victor Imanuel W. Nalle* \\ Department of Constitution Law, Faculty of Law Universitas Katolik Darma Cendika, Surabaya \\ Jalan Dr. Ir. H. Soekarno 201 Surabaya, East Java
}

\begin{abstract}
Some law schools in Indonesia reject socio-legal studies with epistemological arguments that puts jurisprudence as sui generis. Rejection is based argument that jurisprudence is a normative science. In fact socio-legal studies in the development of jurisprudence outside Indonesia has long existed and contributed to the legal reform. Socio-legal studies also significant for legal reform. It is caused by the existence of non doctrinal aspect in law making and implementation of the law. Therefore the position and relevance of socio-legal research is not related to the benefits that provided for the development of national law or jurisprudence.
\end{abstract}

Keywords: sui generis, interdiciplinary approach, legal reform

\section{Intisari}

Beberapa fakultas hukum di Indonesia menolak penelitian sosio-legal dengan argumentasi epistemologis yang menempatkan ilmu hukum sebagai sui generis. Penolakan tersebut didasarkan argumentasi bahwa ilmu hukum adalah ilmu yang bersifat normatif. Kenyataannya studi sosio-legal dalam perkembangan ilmu hukum di luar Indonesia telah lama eksis dan berperan dalam pembaharuan hukum. Selain itu, studi sosiolegal juga berperan dalam pembaharuan hukum. Hal ini disebabkan adanya aspek-aspek nondoktrinal yang berperan dalam pembentukan hukum dan implementasi hukum di masyarakat. Oleh karena itu kedudukan dan relevansi penelitian sosio-legal pada ada tidaknya manfaat yang diberikan bagi perkembangan hukum nasional ataupun ilmu hukum.

Kata kunci: sui generis, pendekatan interdisipliner, pembaharuan hukum

\section{Pokok Muatan}

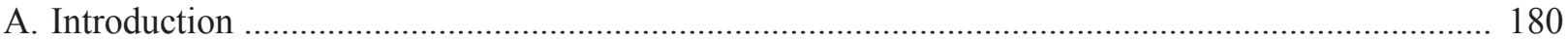

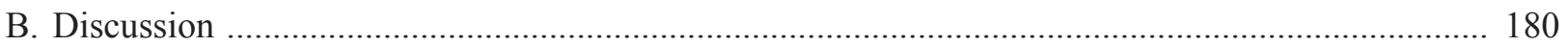

1. Structure of Legal Science and Empirical Studies in Legal Science ........................................ 180

2. The Gap between Facts and Norms: The Relevance of Empirical Research .............................. 182

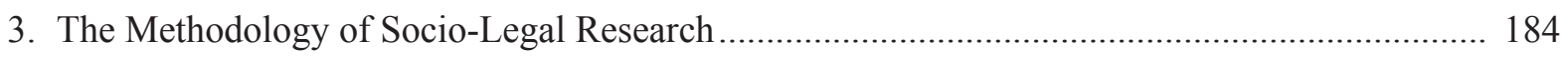

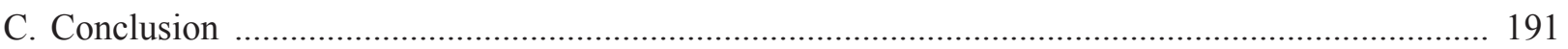




\section{A. Pendahuluan}

In the previous years, the discussion of sociolegal studies in legal science had been debatable. The question would be, are socio-legal studies able to be considered as a legal research. An opposing statement against the socio-legal studies was mentioned by Peter Mahmud Marzuki in his book "Penelitian Hukum". Peter Mahmud Marzuki stated that a socio-legal study is not a legal research since it is placing the law as a social phenomenon. A sociolegal study does not research the law itself, yet, it researches individual behavior and society related to the law. ${ }^{1}$ Therefore, every socio-legal study in legal science has to be rejected.

Unfortunately, this interesting issue was responded by praising one of the type of research and underestimating another type of research. However, in other countries, the type of research in law faculty has no longer been categorized. This uncategorized act can be found in survey of Manderson and Mohr towards the master students of law school in Australia. According to such survey, there are only $20 \%$ of students who conducted a doctrine research or normative research. Another $20 \%$ researched concerning the issue of law reform. The rest of it, they conducted research regarding laws and social movement, post-colonialism, human rights and globalization. Such studies were undertaken by interdisciplinary approach. ${ }^{2}$ This fact shows that praising a normative study and comparing to legal research in foreign university - seems like law schools outside Indonesia still hold the normative study - is irrelevant.

As an issue related to methodology, this issue should be discussed by way of researching the structure of legal science either from epistemology point of view or philosophy. Hence, there is a complete image concerning legal science, in what extent the normative aspect of law and in what extent the empirical aspect of law can be researched. This research raises an important question: is legal science called sui generis has to be seen from the binary opposition? If it is so, thus, the choice of a legal research is take it or leave it. When we are in the academic sphere in which praising the normative study, thus, we can only undertake normative research. The other way around would happen in another different places.

Therefore, this paper will answer three research questions: (1) how is the position of empirical research in the structure of legal science?; (2) what is the relevance of socio-legal research in a relation between normative law with empirical fact?; and (3) what kind of methodology that is applied in socio-legal research for linking normative aspect and empirical aspect in legal science?

\section{B. Discussion}

\section{Structure of Legal Science and Empirical Studies in Legal Science}

Legal Scholars pragmatically agree that there are three layers in legal science that are related to each other. However, not all of the layers have the same opinion regarding what the three studies are in such legal science layers. Gijssels and van Hoecke stated that the three layers of legal science consist of philosophy law, law of theory and law of dogmatic. Law of philosophy is more speculative and based on the reflective study. Law of dogmatic has a normative character and juridical technique of study. As the center of study between law of philosophy and law of dogmatic, there is legal theory that has an analytic study to the principles of law. The interesting point from Gijssels and van Hoecke statement is the character of legal theory is not only normative but also empiric. ${ }^{3}$ Although its

Peter Mahmud Marzuki, 2007, Legal Research, Kencana, Jakarta, p. 87. An opposing statement of Peter Mahmud Marzuki against sociolegal study has been mentioned before Legal Study was published, either in its article of the journals or in the speech of his inauguration as a professor.

Ian Dobinson and Francis Johns, "Qualitative Legal Research”, in Mike McConville and Wing Hong Chui, 2007, Research Methods for Law, Edinburgh University Press, Edinburgh, p. 18.

Philipus M. Hadjon and Tatiek Sri Djatmiati, 2005, Argumentasi Hukum, Gadjah Mada University Press, Yogyakarta, pp. 9 - 11. 
characters are normative and empiric however, it is not clear whether the legal theory can be studied by interdisciplinary approach or not. Finally, such three main studies must be directed into two main aspects in the law practice, which are law making and the implementation of law.

The division of legal science layers stated by Meuwissen. Meuwissen divides three layers of legal science. The first layer is legal philosophy, realizing the entire of legal theory based on a broad sense. In the second layer there is legal theory (in the narrow definition). The upper layer of legal theory (in narrow definition) is legal science that realizes five forms that are legal dogmatic, legal history, comparative law, legal sociology, and legal psychology. Meuwissen mentioned that legal theory in the broad sense is the combination between legal theory (in narrow definition) and the legal science with its five forms. ${ }^{4}$

The opinion of Gijssel, Van Hoecke and Meuwissen indicated that the undergraduate people have the same understanding that law is not researched by a normative approach to build logic proportions. The different thing between Gijssel, Van Hoecke and Meuwissen is how the interdisciplinary approach is applied when they research the law empirically. When placing legal history, legal sociology and psychology as the part of legal theory in the broad sense thus Meuwissen shows that interdisciplinary approach can contribute in developing legal theory.

During the criticism given to the empirical studies in the legal science is a contribution in such study does not exist in legal practice. Empirical legal studies cannot discuss about legal substance so that it cannot contribute practically for legal science. Besides, empirical studies cannot explain the implicit meaning behind the fact. ${ }^{5}$ Hence, legal scholar called its study as sui generis in which its methodology is different from social science. If we have a look on the different perspectives on the legal science layers thus it needs to be asked where such character of sui generis is located? By this fact, whether the legal philosophy layers have methodology that is different from other philosophies?

Meuwissen carefully stated his opinion on the empirical legal studies rejection. Refer to Meuwissen, empirical legal studies can contribute in the legal practice when it does not only explain about the fact. Empirical studies need to explain with the hypothesis. Practically, empirical studies also can be used in organizing the act that is needed by the citizen. However, Meuwiseen also considered if the empirical studies could separate from the values so the studies are in instrumental rationalities. ${ }^{6}$ The Meuwiseen opinion was answering the critic from Hamstead and Freeman that empirical research only explains the gap but explain rarely (the gap is described but is rarely explain). ${ }^{7}$

Criticism of empirical legal studies is also motivated by great anti-positivism spirit by some parties that have a positivist mind in their other mind. Meuwissen is totally wrong to categorize those who study regarding empirical legal science as positivist group. ${ }^{8}$ The assessment of legal science empirically is always assumed that law as a fact that can be determined and must release assessment, norm, or criticism when it is studied. ${ }^{9}$ It is caused by putting aside the development and different perspectives in empirical legal studies research.

Empirical legal studies research is not

\footnotetext{
J.J.H. Bruggink, 1999, Rechtsreflecties, Grondbegrippen uit de rechtstheorie, Refleksi tentang Hukum, diterjemahkan oleh Arief Sidharta, Citra Aditya Bakti, Bandung, p. 162.

This opinion can be seen at Peter Mahmud Marzuki, "Arti Penting Hermeneutika dalam Penerapan Hukum", Speech, Professor Inauguration Faculty of Law Airlangga University, Surabaya, 17 December 2005.

D.H.M. Meuwissen, 2009, "Rechtswetenschap", in B. Arief Sidharta, Meuwissen tentang Pengembanan Hukum, Ilmu Hukum, Teori Hukum, dan Filsafat Hukum, Refika Aditama, Bandung, p. 61.

About Hamstead dan Freeman criticisms look at Philipus M. Hadjon and Tatiek Sri Djatmiati, Op.cit, p. 4.

D.H.M. Meuwissen, Op.cit, p. 59.

Peter Mahmud Marzuki, 2009, Pengantar Ilmu Hukum, Kencana, Jakarta, p. 36.
} 
always about the free value research and separated between morality and law. In some ways, normative approach in some branch of legal science shows the strong effect of positivism. For instance, is analytical jurisprudence. The two figures are, John Austin and Hans Kelsen, they separate clearly between morality and law. For Austin, legal is valid when it is an instruction from the leader. The validity does not depend on the good or bad values in such law. According to Kelsen, the legal validity is determined by the hierarchical structure in the law with validity of a norm that defines the higher norm. ${ }^{10}$ Therefore, the validity is determined by the logic and coherent structure. Kelsen also argued that morality and law are the two different things and should be separated. ${ }^{11}$

If a perspective that see the law normatively can have positivist paradigm, does it have the same way seeing the law empirically? It is true since August Comte so the perspective objectively towards the fact becomes similar to free of value and be categorized as positivism. However, the character of such perspective in law is not identical. It refers to the empirical research by sociologic approach there are two perspectives: scientific sociology of law and the category of perspective is close to the natural law that is normative sociology of law.

Scientific sociology of law, according to Donald Black, is not focused on evaluating a policy in the law. The focus tends to law as a behavior system. This research category is not involved in the good or bad values of a law system. The category is more striking for Hamstead and Freeman critics. Normative sociology of law that was improved by Philip Selznick has many values. Selznick argues that the task of legal sociology is learning the essence of legality and the conditions that are related to legality. ${ }^{12}$ In this case Selznick has the same opinion with naturalism, Lon Fuller, he stated that a law could be considered to be legal when the inside values are fulfilling some terms and conditions. ${ }^{13}$

Selznick also gives his opinion regarding what the values and conditions that are needed by law to make it has the legality. The four conditions such as: legitimacy, rational consensus and competence of citizen, criticism of institutionalization, and institutionalization self-restrain by the rulers. ${ }^{14}$ From the perspective of normative sociology of law, the law is not only accepted as fact, but also needs to be criticized. It is different if it refers to the real positivist perspective from normative perspective. For the followers of such perspective, when a legislation is made by the law makers and is not in contradiction with the higher legislation so that such legislation should be considered to be valid and has the legality.

Therefore, sociologic perspective (as one of approaches in the empirical legal science research) is not monolithic. It is similar to the other approaches in the empirical studies, a stigma that empirical research is always positivistic must be banned. The dualism perspective of sociology approach shows that sociological approach in law does not only explain a fact and can direct specific values into law as desired by naturalists.

\section{The Gap between Facts and Norms: The Relevance of Empirical Research}

The supporters of empirical legal research stated that if there is a gap between law and implementation. In the other term, it can be mentioned as the gap between the fact and the norm. Hence, the critic from Hamstead and

\footnotetext{
Hans Kelsen, Reine Rechtslehre, 2005, Pure Theory of Law, trans: Max Knight, The Lawbook Exchange Ltd., New Jersey, p. 194. Ibid, p. 66

Lee S. Weinberg and Judith W. Weinberg, 1980, Law and Society: an Interdisiplinary Introduction, University Press of America, Lanham, p. $84-92$.

13 The requirements that is mentioned by Fuller as inner morality of law such as: impersonality, famous (known by majority people) is not retroactive, understood clearly, no clash with others regulations, possible and logic, applicable permanently, no clash with law enforcement officer. See Lon Fuller, 1969, The Morality of Law, Revised Edition, Yale University Press, New Haven dan London, p. 39.
}

$14 \quad$ Ibid, p. 85 
Freeman, sometimes, empirical legal research is only explaining such gap. Then, what is the further explanation? In the other critics regarding the discrepancy between facts and norms is that the gap is not a problem anymore related to the law. Such issue is related to the law enforcers, for instance, law enforcement officer. If the traffic act obliges all people to use seat belt, but in fact it is not obeyed, so that is questionable for law enforcement officer. However, is the problem that simple?

In order to make the problem is not simplified it needs to be reviewed from Eugen Ehrlich argument. According to Ehrlich, "every society had an inner order of the associations of human beings which composed it, and this inner order dominated life itself, even though it had not been posted in legal propositions of the positive law". ${ }^{15}$ Ehrlich did not mean to say if positive law is subordinate from customary law. He wanted to say that the discrepancy between fact and norm could be caused by incompatibility of positive law and the customs that had applied in the society.

From the law perspective as social manipulation, the incompatibility of law and customs may have been a deliberation. It means that law becomes an instrument to change or may be clear up such customs. One of the relevant examples is the local regulation in the Central Sumba District. Such local regulation wants to change the customs that has been performing by culture, such as the high cost of wedding (in the form of money, livestock, etc.). Another perspectives, the high cost of social is assumed to be able to close the potential capital that can be used as economic growth.

However, if there is no behavior in the society that want to be changed so the problem that appears from the deliberation of discrepancy between fact and norm can be caused by the problem in its norm itself. This is the real problem that cannot be answered by normative research. Normative research can give prescriptions by referring to principles, values, legal theory, but what happens, if the prescriptions that were given in the norm cannot be well implemented? Can the prescription that becomes the norm and not effective be analyzed only with doctrinal approach? Of course, it will not answer the problems. The discrepancy between fact and norm will always happen.

In the end, when a discrepancy between fact and norm happens it is needed a research regarding legal reform. Legal research reform is not only based on the theory, principle, and legal concepts that are constructed logically. The concrete example is, when the local government wanted to upgrade the amount of advertisement tax since there is an insistence to change it, thus the research cannot be determined by principle, theory and others normative issues. It is needed interdisciplinary approach to reach the formulation norm in such local regulation. It is in accordance with Habermas opinion that law is not narcissistically self-enclosed system. The law also needs sociological approach. Without any perspectives that review the law empirically thus the philosophical concepts concerning the law will be useless. ${ }^{16}$

The needs to see law empirically is also stated by Kees van Waaldijk, as quoted by Wiratraman, that legal research at least can answer nine basic issues. ${ }^{17}$ Of such nine issues five of them have empirical nuance. The nine characters in the legal

\footnotetext{
Ibid, p. 14.

Jurgen Habermas, Faktizitat und Geltung, 1997, Between Facts and Norms: Contribution to a Discourse Theory of Law and Democracy, diterjemahkan oleh William Rehg, Polity Press, Cambridge, p. 461

17 R. Herlambang Perdana Wiratraman, "Penelitian Sosio-Legal dan Pengembangan Pendidikan Hukum di Indonesia: Konteks, Urgensi, dan Tantangannya", Paper, Focus Group Discussion: Socio-Legal Reseacrh in the Future of Law Education in Indonesia, Faculty of Law Universitas Katolik Darma Cendika, 14 May 2013, p. 8.
} 
Table 1. Nine Possibilities of Legal Research Character

\begin{tabular}{|c|c|c|c|c|}
\hline & & \multicolumn{3}{|c|}{ Three types of questions posed } \\
\hline & & $\begin{array}{c}1 \\
\text { De Lege lata: What } \\
\text { does the law hold? }\end{array}$ & $\begin{array}{c}2 \\
\text { How does law } \\
\text { work? }\end{array}$ & $\begin{array}{c}3 \\
\text { De lege formula: } \\
\text { What law would be } \\
\text { desirable? }\end{array}$ \\
\hline \multirow{3}{*}{$\begin{array}{l}\text { Three types of } \\
\text { answer looked for }\end{array}$} & a. Factual & $\begin{array}{c}\text { Descriptive } \\
\text { What do recognised } \\
\text { sources of law hold } \\
\text { about a particular } \\
\text { topic? }\end{array}$ & $\begin{array}{c}\text { Empirical } \\
\text { How does a given } \\
\text { law operate in } \\
\text { practice? }\end{array}$ & $\begin{array}{l}\text { Instrumental } \\
\text { What should the } \\
\text { law say to } \\
\text { contribute to } \\
\text { achieving a given } \\
\text { goal? }\end{array}$ \\
\hline & b. Theoretical & $\begin{array}{l}\text { Conceptual } \\
\text { To what more } \\
\text { general concept can } \\
\text { certain legal rules } \\
\text { be reduced? }\end{array}$ & $\begin{array}{l}\text { Explanatory } \\
\text { What causes can be } \\
\text { found to explain a } \\
\text { given law or its } \\
\text { practical operation? }\end{array}$ & $\begin{array}{l}\text { Fundamental } \\
\text { What should the } \\
\text { law say to be } \\
\text { (more) compatible } \\
\text { with a certain legal } \\
\text { principle? }\end{array}$ \\
\hline & c. Normative & $\begin{array}{c}\text { Supervisory } \\
\text { Is a certain legal } \\
\text { nule compatibel } \\
\text { with higher law? }\end{array}$ & $\begin{array}{c}\text { Evaluative } \\
\text { Does a given law } \\
\text { contribute to } \\
\text { achieving its goal? }\end{array}$ & $\begin{array}{c}\text { Political } \\
\text { What should the } \\
\text { law say to } \\
\text { contribute to the } \\
\text { realization of a } \\
\text { given political } \\
\text { ideal? }\end{array}$ \\
\hline
\end{tabular}

Source: R. Herlambang Perdana Wiratraman, Socio Legal Research and Developtment of Legal Education in Indonesia: Context, Urgentcy, and Its Challenge.

research can be seen in the Table 1.

\section{The Methodology of Socio-Legal Research}

The biggest confusion when an undergraduate law student wants to make socio-legal research is the methodology. Socio-legal research is foreign thing during studying law in the universities. Most of universities mention this issue in the higher level (Magister or doctor) or some university did not mention it at all. The confusion to an ability that must be needed in the socio-legal research will provoke a fear for the undergraduate student with the methodology that should be apllied (Methodological Anxiety Syndrome). ${ }^{18}$

Historically the method is a familiar thing in the legal science. Oliver Wendell Holmes, in the 19th century had predicted the influence of the statisticians especially in law in the future. Even though, Holmes prediction became true, but the influence of legal studies is still complicated.

The influence of socio-legal method pratically started in Muller vs Oregon (1908) case when Oregon Supreme Court examining the Oregon Act which governs regarding the maximum 10 hours work time for woman is constitutional. ${ }^{19}$ Louis
Brandeisas as the lawyer of Oregon, he was using the result of empirical research that described the effect of long working hours and the bad working condition for woman labors. Since that time, the factual data (empirical) became familiar to be used in the court as a consideration. ${ }^{20}$ The report that was delivered Brandies became pioneers in the legal brief in United State of America that does not only depend on legal theory but also factual data.

Learning from Holmes experience regarding the importance of statistic and economic also from Brandies experience that described the factual condition which is relevant with a legal issue, so the methodology in socio-legal can be categorized into two parts: qualitative and quantitative. Referring to the general research, the qualitative and quantitative aspect of the legal research, was often disordered by legal doctrinal research. Sometimes qualitative research is assumed to be the same with doctrinal research, meanwhile quantitative research is the research that is empiric.

The disruption understanding is caused by no proper understanding with regards to what is data. In the socio-legal research, either qualitative or

18 Patrick Schmidt and Simon Halliday, 2009, "Introduction: Beyond Methods - Law and Society in Action", in Simon Halliday and Patrick Schmidt (eds.), Conducting Law and Society Research: Reflection on Methods and Practices, Cambridge University Press, Cambridge, p. 2.

19 Michael Heise, “The Past, Present, and Future of Empirical Legal Scholarship: Judicial Decision Making and New Empiricism”, University of Illinois Law Review, Vol. 2002, No.4, 2002, p. 823

20 Terry Hutchinson, 2002, Research and Writing in Law, Lawbook Co., Pyrmont, p. 89. 
quantitative a researcher is not only involved with legal material but also the data. The data that are collected by the researcher can be a primary data or secondary data. Sometimes, the primary data is considered as the data that has empirical dimension. In fact, the secondary data also has empirical dimension, however, it cannot be obtained directly by the researcher in the "field". Since anything that is called as data have empirical dimension.

Therefore, either qualitative or quantitative research in the socio-legal research are empirical research. This perspective refers to the Epstein and King argument as follows:

What makes research empirical is that it is based on observations of the world, in other words, data, which is just a term for facts about the world. These facts may be historical or contemporary, or based on legislation or case law, the results of interviews or surveys, or the outcomes of secondary archival research or primary data collection. Data can be precise or vague, relatively certain or very uncertain, directly observed or indirect proxies, and they can be anthropological, interpretive, sociological, economic, legal, political, biological, physical, or natural. As long as the facts have something to do with the world, they are data, and as long as research involves data that is observed or desired, it is empirical. ${ }^{21}$

Eventhough, it is hard to find the similarity between qualitative and quantitative research, however, it will be harder to find the difference between qualitative and quantitative research. There are many legal researchers who simplify the difference between the two researches only in a research that uses numbers and the one who does not. In fact, the difference between both type of researches is not that simple. There are many aspects that can be raised as to differentiate between the two. Terry Hutchinson distinguishes quantitative and qualitative research into some aspects, such as: ${ }^{22}$

\section{a. Paradigma}

Quantitative research based on the positivism that tries to put reality as objective as possible and release the values intervention to explain such reality. Qualitative research is not always positivist. The development of postmodernism also influences the paradigm in the qualitative research when the reality is not accepted as an objective issue and single. Postmodernism paradigm no longer sees that the truth is something single or monolithic. There is no single truth so it is changed by the others truths. Hence, qualitative research can show a separate opinion or strange regarding the reality that tries to be explained. Surely, the categorize value and norm still exists for the qualitative researchers who are still using positivist paradigm objectification. The difference such paradigms also shows how the role of truth theory in the evaluating scientific proportion that is produced the both researches. Quantitative research examines how far the correspondence between the proportion in the research hypothesis with the empirical fact. Since, the proportion is compatible with the empirical fact, so it can produce a new scientific theory. Then, when qualitative research has a postmodern paradigm, it needs to be questioned regarding the way to think of its relevance in the social research that tries to examine the scientific proportion with the truth in the reality.

\section{b. Perspective}

Quantitative research always applies an observer perspective. Qualitative research is using insider perspective. Insider perspective has an advantage that is more complete to describe a problem than only using a numbers. The insider perspective

\footnotetext{
${ }_{21}$ Ian Dobinson and Francis Johns, Op.cit, p. 18.
}

22 Terry Hutchinson, Op.cit, p. 92. 
is usually used in the legal anthropological research. The researcher is not the subject in the group, population, or institution that will be researched. Thus, when the researcher is the perpetrator in daily activities, it is possible that the research is bias.

\section{c. Reality Description}

Since the research is always related to numbers, thus the reality in the quantitative research is always as a number. This number was obtained from the population that became a sample. Therefore, in this case the reality is trying to be described by the numbers from the sample in a population or group. This number was attempted to describe the real reality with high standard sampling to avoid the high sampling error. Qualitative research describes the reality as the respondent experience -the individual who are involved in this problem - and there is no standard in experience sampling. Quantitative research is gaining large quantity of respondents, but it is opposite with qualitative research. Qualitative research is gaining a small quantity of respondents and only takes the main sample which determines the legal issues that will be discussed. Surely, the experience coming from a few sample of respondents will be more details and richer than using quantitative research.

\section{d. Investigation Object}

Quantitative research was investigating the facts, then it is described in numbers. Quantitative research was investigating perception. Investigate the perception does not mean only investigate the fact. The individual or group opinion to the fact was also investigated.

\section{e. Hypothesis}

Even though, the difference in the hypothesis is quite different, but it is usually not discussed at the quantitative and qualitative research. Quantitative research based on the hypothesis that is always tested continuously. Therefore, the hypothesis always presented at the beginning and then to test it during the research. Qualitative research can develop the hypothesis either before research or during research. In the previous discussion about the different paradigm, it can be seen that the hypothesis between qualitative and quantitative research with postmodern paradigm has significant difference. In this case the relevance hypothesis on the qualitative research needs to be questioned.

\section{f. Parameter}

The parameter in the quantitative research is surely measurable. The statistic is used for measuring tools in the quantitative research, whereas the quantitative research does not require statistic as the parameter.

\section{g. Writing Style}

Even though, the difference is not a big deal, however, it shows different philosophy between both researches. Quantitative research is usually visualized by way of third party writing style. This writing style shows positivist paradigm that tries to place the author subjectively as an observer. Qualitative research tends to narration writing style or description, so that the result of research is more like a story. This writing style can show insider point of view in qualitative research. The example of this writing style can be seen when reading socio-legal research from Adrian Bedneer towards administrative law in Indonesia. His writing style shows the characteristic of qualitative research that tries to explore the relation between social and reality as an experience from the observer itself. His writing style is different from the writing style of legal research result, in general, in Indonesia in which tends to be rigid and flat.

If the normative research is limited on an approach that still applies legislation as well as principles, thus, the empirical 
approach cannot be avoided from another scientific disciplines. The socio-legal studies evidently cannot be avoided from the sociological approach. However, it is not limited to only one approach. In socio-legal studies, sociological approach can be applied altogether with other approaches. The use of other approaches work when the law and society is related each other with economic system, political development, psychology, and other aspects.

The approaches that can be applied when we conduct socio-legal studies are as follows:

\section{1) Sociological Approach}

It has been discussed that there are two point of views in observing the law from sociological approach. Normative sociology of law point of view develops with the influence from nature law in the context of sociologic. Philip Selznick as an observer in this approach more or less is influenced by the opinions of Lon Fuller. Selznick thinks that the task of legal research from sociological point of view is to learn the meaning of legality and conditions that encourage the legality. Selznick agrees with Fuller that a norm can be a legal norm if such norm fulfills the moral criteria in inner morality of law. Based on Selznick, sociology of law cannot deny the fact that some social control system (including positive law) cannot fulfill legality criteria.

According to Selznick's thought, it can be concluded that its sociology of law influenced by the nature law with only the existence of absolute standard, either its substance or procedural, for grading and evaluating the law and system of law. ${ }^{23}$ Besides, the scientific sociology of law that has been mentioned by Donald Black, was influenced by the development of law positivism which separates between moral and law. For the adherent of this view, the problem of bad and goodness of law should be separated from the whether or not the law is valid. Even though, a legal norm is considered to be worst, yet, it cannot be deemed that the validity of such norm decreases. Donald Black provides the core of his view regarding the socio-legal approach as follow:

It is my contention that a purely sociological approach to law should involve not an assessment of legal policy, but rather, a scientific analysis of legal life as a system of behavior. The ultimate contribution of this enterprise would be a general theory of law, a theory that would predict and explain every instance of legal behavior. While such a theory may never be attained, efforts to achieve it should be central to the sociology of law. By contrast, the core problems of legal policy making are problems of value. Such value considerations are as irrelevant to a sociology of law as they are to any other scientific theory of the empirical world. ${ }^{24}$

\section{b. Political Approach}

The law is a main product of politics. American legal scholar, James Wilson, said that law as the main vein in a governement. ${ }^{25}$ It is obviously important the role of law in a government that cannot be separated from politics so that between those are consitute as a unity which cannot be apart as a system.

The doctrine of there is a unity between law and politics was started from in the middle of 6th century by Bodin, Suarez, Pufendorf and other scholars who assumed 
that the existance of unity between law and politics can be able to determine that a person as a subject of law. The existance of such subject of law constitutes pre condition for the economic development based on contract and workloads distribution. The crucial reason the inseparable doctrine of law and politics is based on the war happened in Hobbes era. Hobbes thinks that the peace cannot be guaranteed only by law. ${ }^{26}$

Nowadays, the development of law in modern politics can be an instrument controling the political life, not the other way around. According to Weinberg and Weinberg, three ideal relationship between law and politics is a relationship that provides a contribution for each other. For political system, the law can provide three important

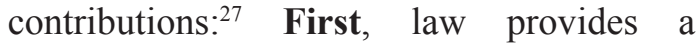
limitation for political authority. One of the example of limitation that be provided by law is the limitation for an incumbent for nominating himself as a president or a head of regional government. A person is limited only capable being a president of head of regional government for maximum two periods consecutively. Law becomes an important instrument for preventing the authority absolutism.

Second, law provides regulation for preventing or solving political confilict that occur. Concretly, the election law governs concerning those who can nominate as a candidate of legislative members, who has the authority to hold the election independently, how much maximal donation that can be given by someone to a candidate, and other provisions.
Third, law constitutes a basis of legitimacy for the process of political decision. For example in parlementary system, law provides procedure for parlements if they are willing to undertake vote of no confidence to minister. The vote of no confidence constitutes a political decision that has its procedural provision so that can be qualified on whether such vote has a legitimacy or not.

Politics, as the law contributes to politics, as well as has a contribution to law. The meeting between politics and law resulted three political studies that has a contibution to law. ${ }^{28}$ First, a study of court from political approach. One of the political approach that can be applied for assessing the court is to analyze the recruitment of judges. This study will describe and provide background informations and characteristics of judges. A background clarification or analyzed characteristics prevalently are age, ethnic, religion, party affiliation, carrier records. The aim of this study is to show that a person with a certain classification dominates either political system or justice system. The main focus of this study is how the various of political factors can describe the behaviour from law decision makers (especially in the court).

The second theory, for example regarding on how politics can influence the court verdict. As we know that a court verdict is not automatically self-excecuting. Sometimes the court verdict already has legality remains cannot be enforced, not being implemented, or it can be enforced after waiting so long. Such circumstances cannot be explained by normative approach. ${ }^{29}$

26 Niklas Luhmann, 2004, Das Recht der Gesellschaft, Law as a Social System, trans: Klaus A. Ziegert, Oxford University Press, Oxford, pp. $359-360$.

27 Lee S. Weinberg and Judith W. Weinberg, Op.cit, pp. $106-107$.

Ibid, pp. $108-110$.

29 However, if there are obstacles to execute the court verdict due to the obstacles occured by principle contradiction thus such research should apply normative approach. For example, obstacles in enforcing the verdict of administrative court. See Yos Johan Utama, "Membangun Peradilan Tata Usaha Negara yang Berwibawa", Speech, Inauguration of Professor of Faculty of Law Universitas Diponegoro, Semarang, 4 February 2010. 
Third theory, regarding the influence of court verdict towards the politics processes and politics agenda. For example in United States is the case Williams v Rhodes (1968). The Supreme Court, in such case, revoked the law of Ohio that prevented George Wallace being nominated in ballot. The governement of Ohio declared their reason that such law has a function for keeping the election system of a simple dwi party. The court held that the law limited the choices of voters. An example in Indonesia is the Constitution Court decision towards the judicial review of Law Number 32 of 2004 that opens chances for candidate in nominating themselves as the head of regional government.

Besides such three examples some other aspects are also interesting to be discussed. For instance, regarding the institution in a court, how the development of developing constitution court so that almost all countries in the world have constitution court or supreme court with similar authorities. Besides discussing form the institutional aspect, it can be assessed by political behaviour aspect. For example a study regarding on how the legislators behave and their background influence the law products.

\section{c. Economics Approach}

Interdiciplinary approach in reviewing law will not be complete without economics apporoach. Since Karl Marx, economics becomes an important variable which influence other variables (politics, religion, education, even law). The intention to accumulate the stock cannot be apart from human being and influence the paradigm in other systems outside economics. The other system, including law, becomes an instrument on how human can satisfy its nature.
Economics approach in law is distinguished into two types. First, positive analysis in which places an assumption that the society responds the law as it is expected by the law maker. For instance, the provision of death penalty influences towards the numbers of murder since people are afraid of killing when he or she is threatened by death penalty. This positive analysis approach later moves on further by way of leading the provisions in order to reflect the economics reasoning. ${ }^{30}$

Second, normative analysis that develops the law for reaching the main purpose is efficiency. Normative analysis in economics approach stands on an assumption that efficiency is the purpose that should be reflected by law and such legislations have to be changed when it is failed to achieve its efficiency. ${ }^{31}$

Economics approach is not only relevant for economic law study. The influnce of free market has lead the paradigm of economic market for products of law which is irrelevant with economics. The paradigm of such free market, for instance, competition, anti-protection, efficiency, and so on.

One of the example of law product which is not related to the education yet interesting for being discusses from economics perspective is the Act of National Education System and the Act of Legal Entity Education (which has been revoked by the Constitution Court). Market liberalization had influenced paradigm as well in education and resulted principles shifting in implementing education around the world, including Indonesia

Education, post liberalization, can be seen merely as the way to develop the individuals in order to be ready for a competition. As a consequence, the education 
will create actors who compete each other in work market. An education as a comodity that can be traded in market for money or status as well becomes a reflection from the market itself. For instance, the high market demand towards the information technology workers will trigger the high offer of education with the basis of information technology. The education is provided generally however it is distributed and accessed privately. As being distributed and accessed privately thus what happens is a competition. Either a competition between service users (the students) or service providers (schools and universities). ${ }^{32}$ The influences of this market economic principle affect to education implementation principle in Education Legal Entity Act which is later revoked by the Consitution Court. ${ }^{33}$

\section{d. Anthropology Approach}

Oliver Wendall Holmes $\mathrm{Jr}$ in 1899 wrote his opinion regarding the relationship between anthropology and law. According to Holmes, "If your subject is law, the roads are plain to anthropology [...] it is perfectly proper to regard and study the law simply as a great anthropological document". ${ }^{34}$ Holmes put the law not as a norm that accidentally appeared in society. Law in history showed that it appeared from the development of human being.

Anthropology in general covers the different patterns of culture in society. Anthropology does not see the society as a one subsystem (politics, law, social structure, and others) as sociology and political science. Anthropology sees the society as a complete unity. Anthropology is eager to avoid ethnocentric perspective so that the study of culture in a society is not aimed to assess or judge.

As a social science, anthropology can ensure the process of law based on the good understanding with regards to culture. If the judiciary proportionally uses anthropological evidences, this can product court verdicts in accordance with reality in socio-culture. Anthropology can keep the law remains credible by providing valid data that are relevant to legal issue. ${ }^{35}$

Such function is more practical in legal practice. For society, especially for those who hold unwritten law, the law has another function. Law Anthropogist $\mathrm{E}$. Adamson Hoebel thinks that law, from law anthropology perspective, is a part from culture which has the following function: ${ }^{36}$

a. Identifying the behaviour which in line with the culture and punish the act that is not in line with the culture so that it keeps the integration in society;

b. Determining the authority and who has the legitimacy in holding the legal norms;

c. Solving case laws occurred in society; and

d. Keeping the harmony in dinamic condition.

If we want to see on how the law functions as what has been described by Hoebel so that it is properly said if anthroology needs to get rid of praising other culture when it researches a certain culture. When we capture law from anthropolgy perspective, it will be inappropriate if it compares or evaluates from the perspective of legal system formed by a state. This kind of understanding will only make the law

\footnotetext{
Mark Olssen, et al., 2004, Education Policy: Globalization, Citizenship and Democracy, SAGE, London, p. 181.

Regarding the influence of free market principles towards the education globally and in Indonesia, it can be seen in Victor Nalle, "Mengembalikan Tanggung Jawab Negara dalam Pendidikan: Kritik terhadap Liberalisasi Pendidikan dalam UU Sisdiknas dan UU BHP", Jurnal Konstitusi, Vol. 8, No. 4, August 2011, pp. 551 - 578.

34 Lee S. Weinberg and Judith W. Weinberg, Op.cit, p. 132.

35 James M. Donovan and H. Edwin Anderson, 2003, Anthropology \& Law, Berghahn Books, New York, p. 63.

36 Lee S. Weinberg and Judith W. Weinberg, Loc.cit.
} 
anthropolgy study will be nothing and having no results with regards to law in a society.

\section{Conclusion}

The debate concerning the socio-legal research whether it is considered as a legal research or not is no longer important. The development of legal research in other countries shows that sociolegal study and other interdiciplinary approach are considered to be important for legal scholars. Such research has advantage in legal reform. Hence, the core problem is whether the socio-legal study provides advantages or not for the development of law or legal science. The issue on whether there is a space or not for empirical legal science research in legal science structure is a matter of pragmatic truth coming from public consent.

Prescriptive nature in legal science research becomes a challenge for empirical legal studies. Empirical research is more descriptive which seeks the relevance between hypothesis and reality. When empirical legal study is not able to provide prescription so that it is difficult to derive in practice. If the empiric research in legal science is not always able to answer such challenge thus the socio-legal research will always be considered not giving advantages. The last century, Louis Brandeis had showed concretely that the empirical study provides advantage for laws practically.

Such challenge needs to be asnwered by socio-legal research avoiding from positivism that is similar to every sociological research. Sociolegal research needs to add normative nature in its research thus it is free from any suggestion. Meaning that, every socio-legal study needs to solve legal issue of normative law related to empirical legal

\section{BIBLIOGRAPHY}

issue that would be researched.

\section{A. Books}

Bruggink, J.J.H, 1999, Rechtsreflecties, Grondbegrippen uit de rechtstheorie (Refleksi Tentang Hukum, trans: Arief Sidharta), Citra Aditya Bakti, Bandung.

Dobinson, Ian and Francis Johns, "Qualitative Legal Research", in Mike McConville and Wing Hong Chui, 2007, Research Methods for Law, Edinburgh University Press, Edinburgh.

Donovan, James M. and H. Edwin Anderson, 2003, Anthropology \& Law, Berghahn Books, New York.

Habermas, Jurgen, 1997, Faktizitat und Geltung (Between Facts and Norms: Contribution to a Discourse Theory of Law and Democracy, trans: William Rehg), Polity Press, Cambridge.

Hadjon, Philipus M. and Tatiek Sri Djatmiati, 2005, Argumentasi Hukum, Gadjah Mada University Press, Yogyakarta.

Hutchinson, Terry, 2002, Research and Writing in Law, Lawbook Co., Pyrmont.
Kelsen, Hans, 2005, Reine Rechtslehre (Pure Theory of Law, trans: Max Knight), The Lawbook Exchange Ltd., New Jersey.

Luhmann, Niklas, 2004, Das Recht der Gesellschaft (Law as a Social System, trans: Klaus A, Ziegert), Oxford University Press, Oxford. , 2007, Penelitian Hukum, Kencana, Jakarta.

2009, Pengantar Ilmu Hukum, Kencana, Jakarta.

Meuwissen, D.H.M, 2009, Rechtswetenschap, Meuwissen (Tentang Pengembanan Hukum, Ilmu Hukum, Teori Hukum, dan Filsafat Hukum, trans: B. Arief Sidharta), Refika Aditama, Bandung.

Miceli, Thomas J, 2004, The Economic Approach to Law, Stanford University Press, Stanford. Olssen,Mark, et al., 2004, Education Policy: Globalization, Citizenship and Democracy, SAGE, London.

Schmidt, Patrick and Simon Halliday, "Introduction: Beyond Methods - Law and Society in Action", in Simon Halliday and 
Patrick Schmidt, 2009, Conducting Law and Society Research: Reflection on Methods and Practices, Cambridge University Press, Cambridge.

Weinberg, Lee S. and Judith W. Weinberg, 1980, Law and Society: An Interdisiplinary Introduction, University Press of America, Lanham.

Whittington, Keith E., et al., "The Study of Law and Politics", in Keith E. Whittington et al., 2008, The Oxford Handbook of Law and Politics, Oxford University Press, Oxford.

\section{B. Journal Articles}

Heise, Michael, "The Past, Present, and Future of Empirical Legal Scholarship: Judicial Decision Making and New Empiricism", University of Illinois Law Review, Vol. 2002, No. 4, 2002.

Nalle, Victor, "Mengembalikan Tanggung Jawab Negara dalam Pendidikan: Kritik terhadap
Liberalisasi Pendidikan dalam UU Sisdiknas dan UU BHP”, Jurnal Konstitusi, Vol. 8, No. 4, August 2011.

\section{Papers/Speech}

Marzuki, Peter Mahmud, "Arti Penting Hermeneutika dalam Penerapan Hukum", Speech, Inauguration of Professor of Faculty of Law Universitas Airlangga, Surabaya, 17 December 2005.

Utama, Yos Johan, "Membangun Peradilan Tata Usaha Negara yang Berwibawa", Speech. Inauguration of Professor of Faculty of Law Universitas Diponegoro, Semarang, 4 February 2010.

Wiratraman, R. Herlambang Perdana, "Penelitian Sosio-Legal dan Pengembangan Pendidikan Hukum di Indonesia: Konteks, Urgensi, dan Tantangannya", Paper, Socio-Legal Reseacrh in the Future of Law Education in Indonesia, Faculty of Law Universitas Katolik Darma Cendika, Surabaya, 14 May 2013. 